Insignia Journal of International Relations

Vol. 6, No.2, November 2019, 106-122

P-ISSN: 2089-1962; E-ISSN: 2597-9868

\title{
Pengaruh Implementasi United Nations Convention Against Corruption Terhadap Pemberantasan Korupsi di Australia Periode 2013-2017
}

\author{
Bhilla Aliffitria \\ Jurusan Hubungan Internasional, Universitas Jenderal Soedirman \\ Email: bhilla.aliffitria24@gmail.com \\ Nuriyeni K. Bintarsari \\ Jurusan Hubungan Internasional, Universitas Jenderal Soedirman \\ Email: nuriyeni@gmail.com
}

\begin{abstract}
Abstrak
Penelitian ini akan mengkaji pengaruh implementasi United Nations Convention Against Corruption (UNCAC) terhadap pemberantasan korupsi di Australia periode 2013-2017, mengingat Australia merupakan salah satu negara yang memiliki perhatian terhadap isu korupsi dan telah meratifikasi UNCAC pada tahun 2005. Tujuan dari penelitian ini adalah mengetahui bagaimana pengaruh implementasi UNCAC terhadap pemberantasan korupsi di Australia periode 2013-2017. Teknik pengumpulan data dengan metode kepustakaan dan memanfaatkan data sekunder dari berbagai sumber yang diperoleh dari buku, jurnal ilmiah, laporan, situs resmi pemerintah dan media online lainnya. Keseluruhan data akan dianalisis menggunakan teori efektivitas rezim yang terdiri dari indikator output, income, dan impact serta indikitor nilai-niai good governance. Hasil dari penelitian ini menunjukkan bahwa perkembangan korupsi di Australia selama tahun 2013-2017 bersifat fluktuatif, beberapa pengimplementasian pasal-pasal UNCAC dan penerapan nilai-nilai good governance dalam upaya pemberantasan korupsi di Australia periode 2013-2017 masih menemui hambatan dan beberapa kritik. Pengimplementasian UNCAC di Australia hanya berpengaruh pada peningkatan jumlah agensi anti-korupsi baik di tingkat negara bagian maupun federal, namun hal tersebut tidak berbanding lurus dengan semakin berkurangnya kasus korupsi yang terjadi di Australia dan meningkatnya skor serta peringkat Indeks Persepsi Korupsi Australia selama tahun 2013-2017.
\end{abstract}

Kata kunci: Australia, efektivitas rezim, korupsi, UNCAC.

\begin{abstract}
This research aims to analyze the influence of the United Nations Convention Against Corruption (UNCAC) implementation on eradicating corruption in Australia from 2013 to 2017. Australia is one of the countries that has prioritized on the corruption issue and has ratified the UNCAC in 2005. The purpose of this study is to know how the UNCAC implementation affectedthe corruption eradication efforts in Australia from 2013 to 2017. Data collection techniques with the literature method and utilizing secondary data from various sources obtained from books, scientific journals, reports, official government sites and other online media. Overall data will be analyzed using the regime effectiveness theory that consist of output, income, and impact indicators and also the values of good governance indicators. The results of this study indicate that the development of corruption in Australia during 20132017 was fluctuating, some implementations of UNCAC articles and the application of good governance values in efforts to eradicate corruption in Australia in the 2013-2017 period still faced obstacles and some criticism. The implementation of UNCAC in Australia only affected in increasing the number of anti-corruption agencies at the state and federal level, but it was not directly proportional to to the reduction of corruption cases and the increase of Australia Corruption Perception Index score and ranking during 2013-2017.
\end{abstract}

Keywords: Australia, corruption, regime effectiveness, UNCAC 


\section{PENDAHULUAN}

Pasca-Perang Dingin, isu low politics seperti ekonomi, hak asasi manusia, lingkungan hidup hingga isu yang berkaitan dengan good governance mulai dianggap penting di kalangan internasional. Selain dinilai dapat menentukan kesejahteraan masyarakat suatu negara, good governance juga merupakan faktor penting untuk memberantas kemiskinan dan mendorong pembangunan (Graham, Amos, \& Plumptre, 2003). Salah satu isu yang berkaitan dengan good governance adalah isu korupsi yang mulai banyak terjadi di berbagai negara. Survei dari Economist Financial Times dan liputan internasional di New York Times mengungkapkan bahwa artikel-artikel berita yang menyebutkan kasus korupsi seperti penggelapan dan suap telah meningkat empat kali lipat antara tahun 1984 dan 1995. Kebangkitan masyarakat sipil telah memicu pengungkapan kasus korupsi yang tidak hanya terjadi di negara bekas blok Uni Soviet, tetapi juga di negaranegara sekutu Barat. Di samping itu, penyebaran pasar, demokrasi, dan globalisasi juga telah meningkatkan peluang terjadinya korupsi (Leiken, 1996).

Korupsi dinilai tidak hanya menghambat kemakmuran ekonomi negara, tetapi juga mempunyai dampak negatif yang kuat bagi kesetaraan ekonomi, legitimasi politik, perdamaian antarnegara, dan kesejahteraan masyarakat. Korupsi kemudian menjadi pusat perhatian institusiinstitusi internasional dan memunculkan institutional revolution dalam ilmu sosial yang dimulai pada awal tahun 1990. Revolusi institusional tersebut menekankan pada pembentukan jenis aturan tertentu demi terwujudnya kesejahteraan masyarakat. Hal ini memberikan agendaperubahan terkait korupsi yang dilakukan oleh kebijakan organisasi internasional, salah satunya adalah Perserikatan Bangsa-Bangsa (PBB) yang mulai menjadikan anti-korupsi sebagai isu utama dengan menetapkan United Nations Convention Against Corruption (UNCAC) yang mulai berlaku pada tanggal 14 Desember 2005 (Uslaner, 2012).

UNCAC merupakan instrumen global anti-korupsi pertama yang mengikat secara hukum dan mendesak negara-negara untuk menciptakan kerangka kerja hukum dan kebijakan yang sesuai dengan standar global. UNCAC juga diciptakan sebagai rezim internasional untuk mengatasi korupsi secara lebih efektif. Konvensi ini mencakup lima bidang utama, yakni tindakan pencegahan; kriminalisasi dan penegakan hukum; kerja sama internasional; pemulihan aset; serta bantuan teknis dan pertukaran informasi. Konvensi ini juga mencakup definisi dari berbagai bentuk korupsi seperti suap, penyalahgunaan fungsi dan berbagai tindakan korupsi di sektor swasta (United Nations Office on Drugs and Crime, 2013).

UNCAC telah diratifikasi oleh 186 negara, termasuk Australia yang telah meratifikasi pada tahun 2005 (Transparency International, 2018). Australia meratifikasi UNCAC melalui Australia Criminal Code 1995 (as amended 2007), Australia Crime Commission Act 2002 (as amended 2009), Australia Anti-Terrorism Act 2005, dan Australia Law Enforcement Integrity Commissioner Act 2006 (United Nations Office on Drugs and Crime, 2014). Australia meratifikasi UNCAC karena ia menilai bahwa korupsi merupakan suatu permasalahan serius yang dapat menghambat ekonomi negara jangka panjang, merusak perkembangan manusia, melemahkan penegakan hukum dan merusak kepercayaan pada pemerintah. Oleh karena itu, melalui ratifikasi UNCAC diharapkan dapat meningkatkan keterlibatan dan kerja sama yang lebih kuat antara negara, lembaga nasional, internasional, masyarakat sipil dan aktor non-pemerintah lainnya dalam memberantas korupsi (Arnold, 2017).

Penulis tertarik untuk mengkaji Australia, karena Australia merupakan salah satu negara yang sukses dalam memberantas korupsi, hal ini dibuktikan melalui grafik rank yang dicapai Australia 
dalam Control of Corruption, Government Effectiveness, dan Voice \& Accountability yang dikeluarkan oleh The Worldwide Governance Indicators (WGI) Project tahun
2013-2017, dimana Australia selalu mencapai angka 90-an di setiap indikator tersebut (WGI, 2017).

Tabel 1

Grafik Skor Australia dalam WGI Project Tahun 2013-2017

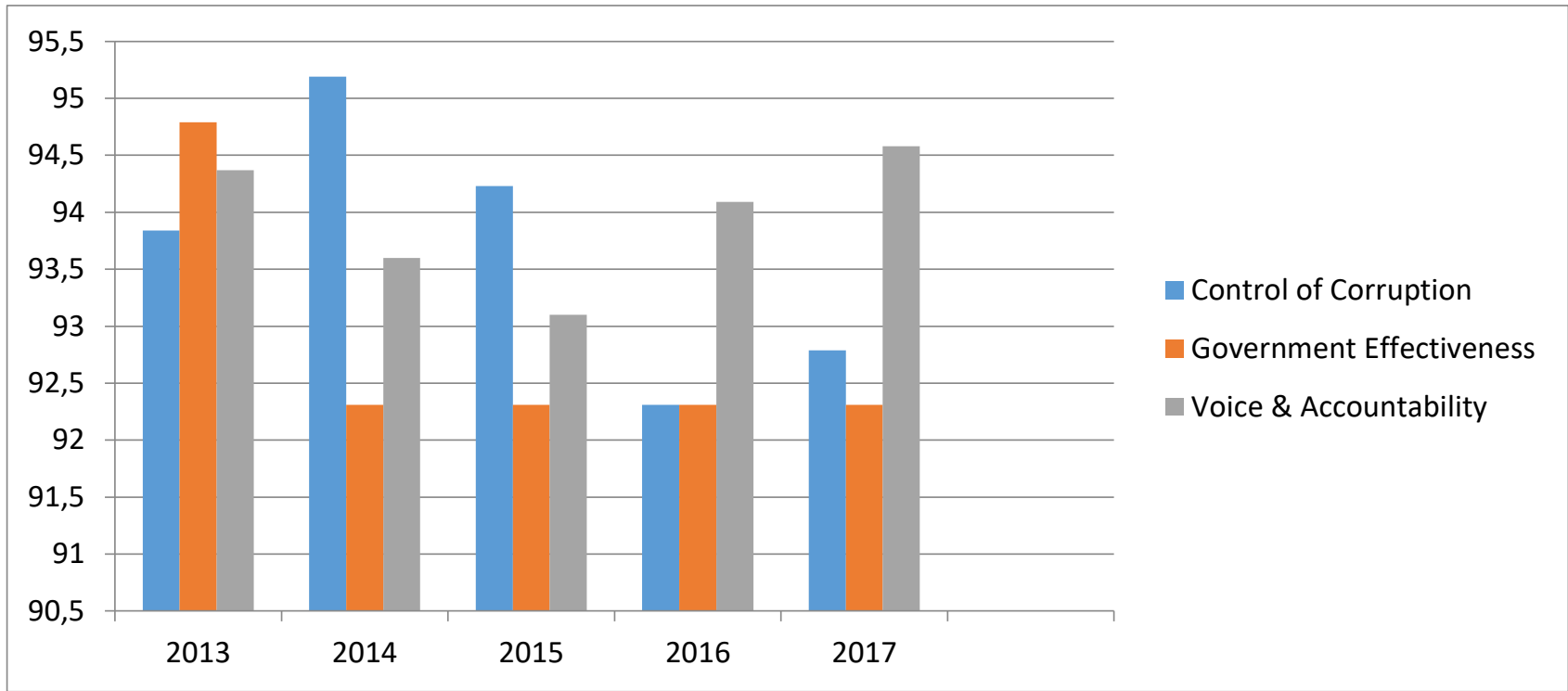

Sumber: The Worldwide Governance Indicators (WGI) Project, 2017.

Namun menariknya, berdasarkan Corruption Perception Index (CPI) dari Transparency International, skor Australia pada periode 2013-2017 mengalami penurunan. CPI mulai diterbitkan pada tahun 1995 oleh Transparency International yang berisi peringkat dan skor negaranegara dengan skala 0 sampai 100 , dimana 0 berarti sangat korup dan 100 sangat bersih. Peringkat dan skor Australia menurut CPI dapat dilihat dalam grafik berikut ini: 
Tabel 2

Grafik Skor dan Peringkat Australia dalam CPI

Tahun 2013-2017

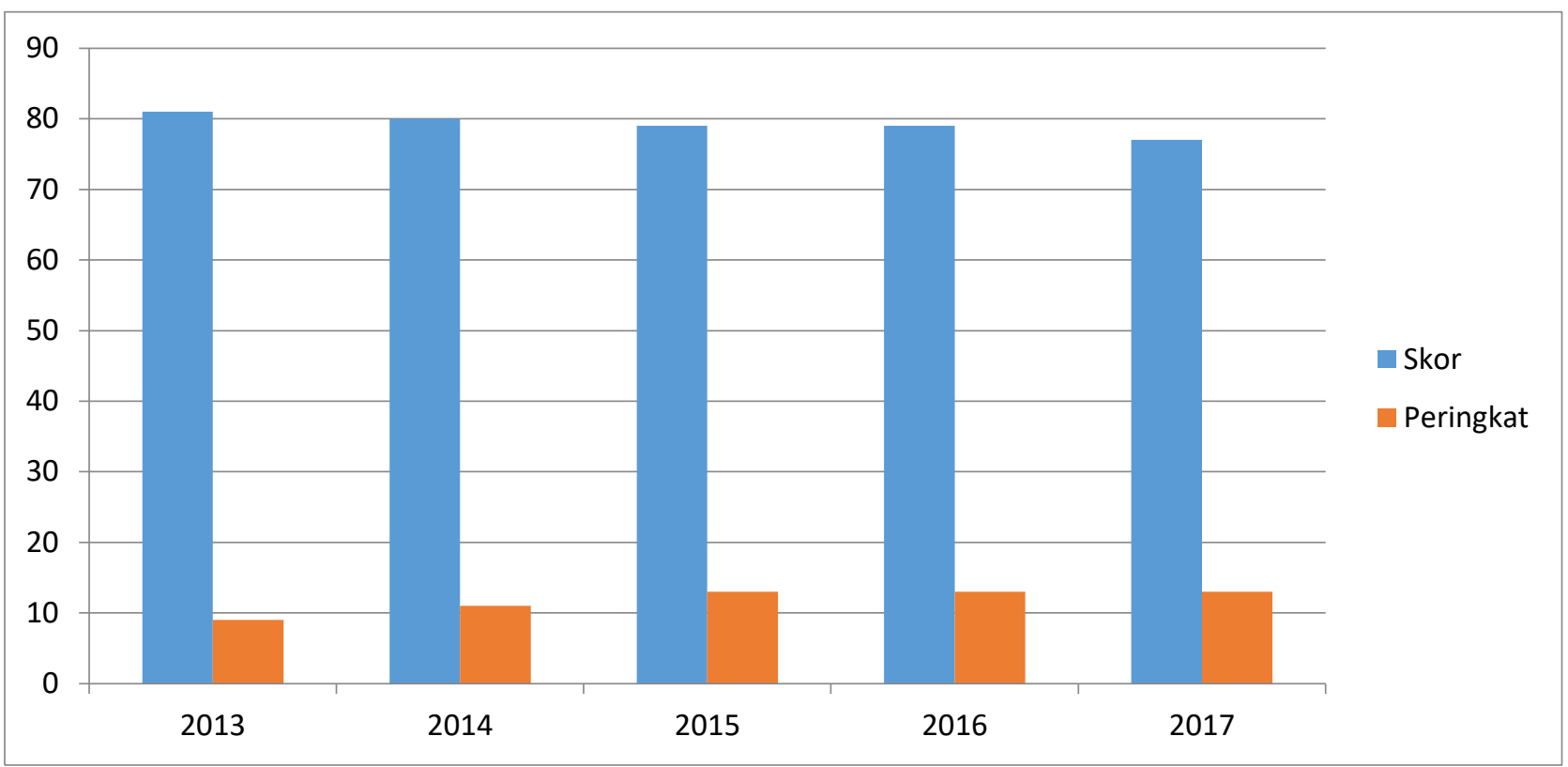

Sumber: Corruption Perception Index Transparency International, 2013-2017.

Menurut Transparency International, penurunan skor CPI Australia terjadi karena pertama, tidak adanya tindakan dari pemerintah dalam menangani korupsi di sektor publik, dan kedua, jajak pendapat, studi, dan survei terbaru telah menunjukkan bahwa kepercayaan masyarakat terhadap pemerintah berada pada titik terendah. Sebuah penelitian yang dilakukan University of Canberra pada tahun 2016 menemukan hanya $5 \%$ orang Australia yang percaya pada pemerintah. Selain itu, sebuah jajak pendapat yang ditugaskan oleh Australia Institute mengungkapkan $85 \%$ responden berpikir bahwa terdapat praktik korupsi di dalam politik federal (Aulby \& Campbell, 2018). Oleh karena itu, berdasarkan data di atas penulis ingin menyoroti bagaimana pengaruh implementasi United Nations Convention Against Corruption (UNCAC) terhadap pemberantasan korupsi di Australia periode 2013-2017.

\section{Kerangka Pemikiran \\ Konsep Good Governance}

Pemerintahan yang baik terdiri dari keberadaan mekanisme, proses dan institusi yang efektif dimana setiap warga negara mengartikulasikan kepentingan mereka, menjalankan hak-hak hukum, memenuhi kewajiban dan menengahi perbedaan. Terdapat lima indikator atau karakteristik dari good governance (International Fund For Agricultural Development, 1999). Pertama, participation, berarti bahwa semua warga baik pria maupun wanita harus memiliki suara dalam pengambilan keputusan baik secara langsung atau melalui lembaga perantara yang sah yang mewakili kepentingan mereka. Kedua, rule of law, berarti bahwa kerangka hukum yang dijalankan suatu negara harus adil dan diberlakukan tanpa pandang bulu. Ketiga, transparency. Transparency harus dibangun berdasarkan informasi yang bebas. Seluruh proses pemerintah, lembaga, dan informasi harus dapat diakses oleh pihak-pihak yang berkepentingan serta informasi yang tersedia harus memadai agar dapat dimengerti dan dipantau. Keempat, equity, berarti bahwa semua warga suatu negara memiliki kesempatan untuk memperbaiki atau mempertahankan kesejahteraan mereka. Kelima, effectiveness and efficiency, 
berarti bahwa proses pemerintahan dan lembaga-lembaga harus memberikan hasil yang sesuai dengan kebutuhan masyarakat dan dengan menggunakan sumber daya yang ada secara optimal.

Konsep ini relevan dengan isi UNCAC yang menekankan terselenggaranya poinpoin good governance di setiap negara (UNODC, 2019), sehingga konsep ini digunakan untuk membantu menganalisis sejauh mana Australia telah menerapkan nilai-nilai good governance sebagai salah satu upaya pemberantasan korupsi.

\section{Teori Efektivitas Rezim}

Olav Schram Stokke (2006) mengemukakan bahwa efektivitas rezim dalam menyelesaikan masalah tergantung pada tiga aspek, yakni output (keputusan), outcome (perilaku), dan impact (dampak). Output berarti meneliti kepatuhan hukum dengan komitmen internasional dan menyoroti kegiatan legislatif serta program nasional dalam menanggapi rezim internasional. Outcome berarti perilaku aktor atau negara yang terlibat dalam penerapan aturan rezim terkait isu yang dihadapi. Impact berarti menggambarkan tingkat keberhasilan sebuah rezim dalam mewujudkan tujuannya karena rezim internasional berperan untuk mewujudkan tujuan negara (Stoke, 2006). Dalam penelitian ini, output digunakan penulis untuk membantu menganalisis kepatuhan hukum Australia terhadap UNCAC dengan menyoroti kegiatan legislatif serta program nasional Australia. Outcome digunakan untuk membantu menganalisis perilaku aktor yang terlibat dalam penerapan UNCAC, dalam hal ini adalah Pemerintah Australia seluruh lapisan masyarakat Australia. Impact membantu menganalisis tingkat keberhasilan UNCAC dalam memberantas korupsi di Australia, karena UNCAC mempunyai tugas dalam memberantas korupsi melalui pengembangan perundangundangan, lembaga yang efektif dan kerja sama antikorupsi internsional yang efektif (Arnold, 2017).

\section{Metode Penelitian}

Penelitian ini menggunakan jenis penelitian kualitatif yang bersifat deskriptifeksplanatif. Tipe penelitian ini digunakan untuk menggambarkan dan menjelaskan sebuah penelitian (Gulo, 2000). Sumber data yang digunakan dalam penelitian ini adalah sumber data sekunder, yaitu berupa datadata yang diambil melalui buku-buku literatur, data-data resmi pemerintah, jurnal ilmiah, laporan statistik dan data-data tambahan lainnya yang berkaitan dengan penelitian (Sarwono, 2006). Dalam penelitian ini berarti berupa data-data yang diambil melalui literatur terkait dengan tema korupsi secara umum dan khususnya korupsi di Australia, data-data resmi pemerintah baik berupa statistik maupun penjelasan pemerintah di laman resmi mereka, artikel-artikel di jurnal ilmiah yang relevan dengan tema penelitian ini, laporan statistik per negara bagian di Australia, dan data tambahan lainnya yang berkaitan dengan penelitian ini.

\section{HASIL DAN PEMBAHASAN \\ Perkembangan Pemberantasan Korupsi di Australia Periode 2013-2017}

Australia menggunakan pendekatan multi-agensi atau dengan membentuk beberapa lembaga antikorupsi baik di tingkat federal maupun di setiap negara bagian dan teritorial. Northern Territory Independent Commission Against Corruption (NT ICAC) baru dibentuk tahun 2018 (Office of the Independent Commissioner Against Corruption, 2018), dan Australian Capital Territory Integrity Commission juga baru akan dibentuk dan beroperasi di tahun 2019 (ACT Government, 2018), sehingga tidak terdapat data laporan terkait korupsi yang terjadi di wilayah tersebut selama periode 2013-2017. Berikut ini perkembangan korupsi di Australia periode 2013-2017 berdasarkan laporan beberapa lembaga antikorupsi di Australia.

Independent Commision Against Corruption (ICAC)-New South Wales (NSW) 
Berdasarkan laporan tahunan lembaga ini, jumlah orang yang telah terbukti korupsi di tahun 2013-2014 sebanyak 41 orang. Pada tahun 2014-2015 dan 2015-2016 berturut-turut jumlahnya mengalami penurunan yakni 17 dan 9 orang, sedangkan pada tahun 2016-2017 bertambah 2 orang menjadi 11 orang dari periode sebelumnya (ICAC NSW Annual Report, 2013-2017). Penambahan 2 orang tersebut tidak dijelaskan secara detail baik dalam ICAC NSW Annual Report maupun di media-media Australia pada periode tersebut, sehingga penulis mengasumsikan bahwa penambahan 2 orang tersebut tidak berarti signifikan terhadap kenaikan jumlah korupsi di Australia.

\section{Independent Broad-based Anti-Corruption Commission (IBAC)-Victoria}

Berdasarkan laporan tahunan dari lembaga ini, pada tahun 2013-2014 IBAC menginvestigasi 28 kasus dan tidak ada kasus yang berkembang ke proses pidana. Pada tahun 2014-2015, IBAC melakukan investigasi terhadap 29 kasus dan 3 diantaranya berkembang ke proses pidana, sedangkan pada tahun 2015-2016 bertambah menjadi melakukan investigasi 34 kasus dan 3 diantaranya berkembang ke proses pidana. Pada tahun 2016-2017 investigasi IBAC bertambah menjadi 46 kasus dan 6 diantaranya yang terdiri dari 23 orang berkembang ke proses pidana (IBAC Victoria Annual Report 2013-2017). Jumlah investigasi yang meningkat dari tahun 20132017 menunjukkan bahwa IBAC semakin teliti dalam memandang sebuah kasus dan semakin aktif dalam menghalangi adanya tindakan korupsi, karena investigasi dilakukan tidak hanya bertujuan untuk mengungkap kasus korupsi tetapi juga untuk menghalangi dan mencegah tindakan tersebut (IBAC Victoria, 2017).

\section{Independent Commisioner Against} Corruption (ICAC) and The Office for Public Integrity (OPI)-South Australia
Berdasarkan laporan tahunan dari lembaga ini, pada tahun 2013-2014, ICAC OPI menginvestigasi 71 kasus yang berpotensi korupsi. Pada tahun 2014-2015, jumlah kasus yang diinvestigasi menjadi 82 dan menghasilkan hukuman terhadap 12 petugas publik. Pada tahun 2015-2016, ICAC OPI menginvestigasi 86 kasus dan 13 orang diantaranya telah dinyatakan bersalah. Pada tahun 2016-2017, jumlah pengaduan yang diinvestigasi menjadi 64 kasus dan 7 orang dinyatakan bersalah dalam tindak pidana korupsi (ICAC OPI South Australia Annual Report, 2013-2017).

\section{Crime and Corruption Commission (CCC)- Queensland}

Bersumber dari laporan tahunan lembaga ini, pada tahun 2013-2014 CCC menunjuk 8 orang yang didakwa atas pelanggaran tindakan korupsi. Pada tahun 2014-2015, jumlah orang yang didakwa meningkat menjadi 200 orang. Pada tahun 2015-2016 menurun menjadi 19 orang, dan tahun 2016-2017 bertambah 4 orang menjadi 23 orang (CCC Queensland Annual Report, 2013-2017).

\section{Corruption and Crime Commission (CCC)- Western Australia}

Pada setiap laporannya, CCC menggabungkan antara bentuk tindakan korupsi dengan bentuk pelanggaran lainnya, sehingga penulis tidak dapat melihat secara spesifik kasus korupsi yang terjadi di Australia Barat dan hanya dapat melihat data dugaan pelanggaran periode 20132017 secara keseluruhan. Pada tahun 20132014, CCC melakukan 178 investigasi dan menjatuhkan hukuman terhadap 12 orang, pada tahun 2014-2015 jumlah investigasi bertambah menjadi 379 dan menghasilkan hukuman terhadap 13 orang. Peningkatan jumlah 1 orang ini tidak dijelaskan secara detail baik dalam CCC WA Annual Report maupun media-media Australia, sehingga penulis mengasumsikan bahwa peningkatan jumlah tersebut tidak berarti signifikan. Kemudian pada periode tahun 2015-2016 
dan 2016-2017 berturut-turut jumlah investigasi menurun menjadi 79 dan 71 sedangkan jumlah orang yang dijatuhi hukuman juga menurun menjadi 4 dan 3 orang (CCC Western Australia Annual Report, 2013-2017).

\section{Tasmanian Integrity Commission (TIC)- Tasmania}

Pada setiap laporannya, TIC sama seperti CCC Australia Barat yang menggabungkan antara bentuk tindakan korupsi dengan bentuk pelanggaran lainnya, sehingga penulis tidak dapat melihat secara spesifik kasus korupsi yang terjadi di Tasmania dan hanya dapat melihat jumlah pelanggaran secara keseluruhan. Pada tahun 2013-2014 terdapat 660 kasus pelanggaran hukum dan menurun pada tahun 2014-2015 menjadi 478. Pada tahun 2015-2016 kembali menurun menjadi 302 kasus dan pada tahun 2016-2017 menjadi 339 kasus pelanggaran (TIC Annual Report, 20132017).

Australian Commission for Law Enforcement Integrity (ACLEI)

ACLEI berperan sebagai badan yang menyelidiki masalah korupsi yang berhubungan dengan penegakan hukum, memberikan pemahaman dan mencegah korupsi di tingkat federal. Perannya ini juga dibantu oleh Australia Federal Police (AFP) dan Australian Criminal Intelligence Commission (ACIC) dalam menemukan kasus korupsi dan kemudian menyerahkannya kepada ACLEI (ACLEI, 2019). Bersumber dari data laporan tahunan ACLEI, selama tahun 2013-2017 jumlah investigasi yang dilakukan ACLEI terus meningkat. Pada tahun 2013-2014 ACLEI melakukan 45 investigasi dengan 11 orang terbukti melakukan korupsi. Pada tahun 2014-2015 jumlah investigasi bertambah menjadi 75 dengan 8 orang terbukti korupsi. Jumlah investigasi juga meningkat di periode tahun 2015-2016 dan 2016-2017 berturut-turut yakni sebanyak 144 dan 242, meskipun demikian jumlah orang yang terbukti korupsi menurun menjadi 3 dan 5 dibandingkan tahun 2014-2015 (ACLEI Annual Report, 2013-2017).

Menurut KPMG Australia, motivasi paling banyak seseorang melakukan korupsi adalah karena tekanan finansial dan sifat tamak (62\%), kemudian sisanya karena faktor lain seperti budaya organisasi, kesempatan, kehilangan kepercayaan diri, dan lain-lain (KPMG Australia, 2017). Berdasarkan data dari beberapa lembaga anti-korupsi di atas, dapat dipersepsikan bahwa perkembangan korupsi di Australia tahun 2013-2017 bersifat fluktuatif. Walaupun beberapa ahli melalui CPI mengungkapkan bahwa perkembangan korupsi Australia selama tahun 2013-2017 memburuk, namun korupsi merupakan fenomena yang tidak bisa diukur atau dibuktikan secara akurat. Hal ini memunculkan kemungkinan bahwa persepsi para ahli dan kenyataan bisa tidak sepenuhnya sesuai (Donaldson, 2019).

\section{Pengaruh Implementasi UNCAC terhadap Pemberantasan Korupsi di Australia Periode 2013-2017}

Pada bagian ini, penulis akan menganalisis pengaruh implementasi UNCAC dari sisi output, outcome, dan impact terhadap pemberantasan korupsi di Australia.

Output - meneliti kepatuhan hukum Australia terhadap UNCAC dengan menyoroti kepatuhan Australia dalam mengimplementasikan beberapa pasal UNCAC.

Pasal 5 dan 6 UNCAC menjelaskan pembentukan kebijakan dan praktik pencegahan korupsi serta pembentukan badan atau badan-badan pencegahan korupsi.Dalam mengimplementasikan pasal ini, Australia telah membentuk beberapa aturan hukum seperti Parliamentary Service Act 1999, Commonwealth Electoral Act 1918 (CEA), Freedom of Information Act (FOIA), Corporations Act 2001, Public Interest Disclosure Act 2013 (PIDA), Public, 
Governance, Performance and Accountability Act 2013 (PGPA), dan Commonwealth Procurement Rules (CPR) untuk memajukan integritas, transparansi, dan akuntabilitas baik dalam sektor privat maupun publik dalam mencegah korupsi. Australia juga telah mengembangkan Open Government National Action Plan 2016-2018 bersama dengan masyarakat sipil. Rencana aksi nasional tersebut berisi 15 komitmen untuk meningkatkan rezim anti-korupsi Australia, seperti integritas sektor publik, partisipasi masyarakat, akses terhadap informasi pemerintah, serta transparansi dan akuntabilitas dalam bisnis. Dalam mengimplementasikan pasal ini, Australia menggunakan pendekatan multi-agensi untuk mencegah dan memberantas korupsi, seperti Australian Federal Police (AFP), Australian Public Service Commission (APSC), Australian Securities and Investments Commission (ASIC), dan Australian Commission for Law Enforcement Integrity (ACLEI) (United Nations, 2019).

Selama periode 2013-2017, penulis mempersepsikan aturan hukum dan lembaga multi-agensi di telah membantu penegakan hukum di Australia, namun dalam implementasiannya masih terdapat keraguan terhadap efektivitas antarlembaga dalam menangani korupsi. Jika dilihat dari perkembangan kasus korupsi pada periode 2013-2017 yang masih fluktuatif dan penurunan skor dalam CPI penulis mempersepsikan bahwa kinerja lembaga multi-agensi belum sepenuhnya maksimal. Australia membutuhkan lembaga antikorupsi tunggal yang membawahi setiap lembaga antikorupsi di bawah satu kerangka kohesif bersama, sehingga kinerja setiap lembaga antikorupsi dapat terkoordinasi dengan baik dan menjalankan tugas secara maksimal. Hal ini sejalan dengan laporan Transparency International yang menyatakan bahwa Australia membutuhkan lembaga antikorupsi federal yang mengawasi dan mengkoordinir setiap lembaga serta melakukan audiensi publik untuk meningkatkan kepercayaan masyarakat terhadap pemerintah (Transparency International, 2017).

Pasal 8 UNCAC menjelaskan tentang pembentukan kode etik bagi pejabat publik.Dalam mengimplementasikan pasal ini, Australia memiliki Commonwealth Electoral Act 1918 (CEA) yang berisi kualifikasi dalam pemilihan umum (sect. 16 dan 34) dan juga diskualifikasi (sect. 44 dan 45) terhadap anggota parlemen dan senator. CEA juga mengatur pengungkapan dana yang diterima selama proses pemilihan, seperti donasi, pinjaman, utang, dan hadiah yang diterima. Kemudian, tanggal ketika menerima, jumlah, nama dan alamat dari pendonor pun harus diungkapkan. Selain itu, Public, Governance, Performance and Accountability Act 2013 (PGPA) yang dimiliki Australia juga memberlakukan serangkaian tugas umum kepada pejabat terkait, seperti standar integrits dan kesopaan untuk menteri, asisten menteri dan sekretaris parlemen dalam menjalankan aktivitas publik (United Nations, 2019). Implementasi CEA dan PGPA belum maksimal: selama periode 2013-2017 masih terdapat ketidakpercayaan masyarakat Australia terhadap integritas proses pemilihan umum, khususnya terkait denganpengungkapan danakampanye. Hal ini dibuktikan dalam The Joint Standing Committee on Electoral Matters yang meninjau pemilihan federal tahun 2016 yang menyatakan bahwa 48\% masyarakat Australia tidak puas dengan sistem demokrasi pada saat itu. Kemudian, terdapat beberapa organisasi seperti GetUp, Green Groups, Church Groups dan organisasi industri yang berkampanye dan mengumpulkan sejumlah dana yang tidak diketahui oleh Australian Electoral Commission (AEC) (The Guardian Australia, 2017). Penulis menilai bahwa implementasi kedua aturan ini perlu dikaji lebih lanjut.

Pasal 15 dan 16 UNCAC menjelaskan tentang kriminalisasi dan penegakan hukum terkait penyuapan pejabat publik nasional, asing, dan pejabat organisasi internasional.Dalam mengimplementasikan pasal ini, Australia mempunyai Criminal 
Code 1995 Section 141 dan 142 yang menangani pelanggaran berkaitan dengan suap domestik pejabat publik domestik dan Section 70.1 dan 70.2 yang menangani suap pejabat publik asing. Setiap negara bagian dan teritori juga memiliki undang-undang kejahatan, hukum pidana atau undangundang pemerintah daerah yang mengatur perilaku pejabat publik pemerintah negara bagian dan daerah. Semua yurisdiksi tersebut melarang pembayaran baik langsung maupun tidak langsung, penawaran suap kepada pejabat publik dan penerimaan suap oleh pejabat publik. AML/ CFT (2006) yang dimiliki Australia juga mengatur pengadaan deteksi kejahatan penyuapan asing. Hukuman bagi pelaku penyuapan asing untuk individu maksimal 10 tahun atau denda $\$ 2,1$ juta, sedangkan untuk korporasi maksimal \$21 juta (United Nations, 2012). Selama periode2013-2017, pelaksanaan aturan hukum terkait penyuapan asing dipersepsikan kurang maksimal. Menurut jurnalis investigasi, Nick McKenzie, hanya terdapatsejumlah kecil kasus yang diselidiki oleh AFP dan sebagian besar kasus yang diselidiki pun belum menghasilkan penuntutan. Hal ini disebabkan oleh kompleksitas kasus-kasus yang terjadi, kurangnya keahlian yang cukup, keterlambatan, sertakurangnya kerja sama dan sumber daya yang terbatas (Commonwealth of Australia, 2018).

Ketidakmaksimalan penegakan hukum terkait penyuapan asing ini juga dibuktikan melalui laporan evaluasi OECD terhadap Australia terkait denganimplementasi konvensi pemberantasan suap pejabat publik asing. Laporan tersebut mengungkapkan bahwa penegak hukum Australia sering menghadapi kesulitan dalam menginvestigasi pelanggaran suap asing, khususnya dalam mendapatkan bukti dari sumber di luar negeri (King \& Mallesons, 2018). Berdasarkan data tersebut, penulis memandang bahwa Australia masih perlu untuk meningkatkan kinerja aturan hukum terkait penyuapan asing dan pelaksanaanpasal ini masih membutuhkan pengkajian lebih lanjut.

Outcome - meneliti perilaku aktor yang terlibat dalam penerapan UNCAC, dalam hal ini adalah Pemerintah Australia dan seluruh lapisan masyarakat Australia dengan menggunakan prinsip-prinsip good governance.

\section{Participation}

Australia menyadari pentingnya peran dan partisipasi masyarakat dalam menunjang kesuksesan negara, termasuk dalam pemberantasan korupsi. Setiap lembaga antikorupsi di Australia menerima pengaduan dan saran terkait korupsi secara daring. Masyarakat Australia menyadari pentingnya peran mereka dalam membantu mengurangi tindakan-tindakan yang dapat merugikan negara. Selama periode 20132017, penulis menemukan bahwa masyarakat Australia telah aktif dalam melaporkan tindakan korupsi melalui pemanfaatan sistem daring yang disediakan oleh masing-masing agensi, sehingga agensi terbantu menjalankan peran mereka dalam memberantas korupsi. Hal ini ditunjukkan melalui laporan tahunan semua agensi negara bagian dan federal yang menyertakan jumlah pengaduan korupsi yang diterima dari masyarakat. Partisipasi tersebut juga dibuktikan melalui Global Corruption Barometer tahun 2017 yang menyatakan bahwa Australia merupakan salah satu dari 17 negara dimana 90\% masyarakatnya memiliki kepedulian dan kesediaan untuk melaporkan tindakan korupsi. Masyarakat Australia juga memiliki persentase paling tinggi, yakni $80 \%$, dalam optimisme mereka memberantas korupsi dibandingkan negara-negara Asia Pasifik lainnya (Transparency International, 2017).

\section{Rule of Law}

Australia membentuk beberapa aturan hukum yang melarang tindakan korupsi baik di tingkat federal maupun negara bagian. Salah satu aturan hukum di tingkat federal 
yang melarang korupsi pejabat publik domestik dan asing adalah the Criminal Code Part 7.6. Setiap negara bagian dan teritorial Australia juga memiliki perundangundangan yang melarang tindakan korupsi publik maupun swasta. Peraturan tersebut antara lain:New South Wales - Section 249B of the Crimes Act 1900;Victoria - Section 176 of the Crimes Act 1958; South Australia Section 150 of the Criminal Law Consolidation Act 1935; Queensland - Sections 442B-442BA of the Criminal Code Act 1899;Western Australia - Sections 529-530 of the Criminal Code; Tasmania - Section 266 of the Criminal Code Act 1924; Austraian Capital Territory Sections 356-357 of the Criminal Code 2002; dan Northern Territory - Section 236 of the Criminal Code Act 1983. Semua sistem hukum yang dibentuk Australia tersebut berlaku bagi setiap individu tanpa memandang siapa mereka (Redlich, 2018).

Sejak tahun 1988, Australia mulai membentuk lembaga antikorupsi di setiap negara bagian, dimulai dengan membentuk the Independent Commission Against Corruption (ICAC) yang didirikan oleh Pemerintah NSW sebagai bentuk peningkatan kepedulian masyarakat terhadap integritas administrasi publik di NSW. Kemudian dilanjutkan dengan pembentukanthe Queensland Crime \& Corruption Commission (1991), the WA Corruption \& Crime Commission (1992), the Tasmanian Integrity Commission (2010), the Victorian Independent Broad-based Anticorruption Commission (2012), danthe SA Independent Commissioner Against Corruption(2012). Lembaga-lembaga tersebut memiliki fungsi inti yang sama dengan berfokus pada investigasi, pencegahan, dan pendidikan antikorupsi. Selain itu, Australia juga membentuk lembaga multi-agensi yang bertugas menangani korupsi. Misalnya, pertama, Australian Commission for Law Enforcement Integrity (ACLEI) tahun 2006 yang berperan menyelidiki masalah korupsi berkaitan dengan penegakan hukum. Kedua, $A F P$ Fraud \& Anti-Corruption Centre tahun 2014 yang berperan menangani penipuan dan korupsi yang dilakukan oleh pegawai pemerintah, penyuapan asing, dan kejahatan identitas kompleks yang melibatkan pembuatan dan penyalahgunaan kredensial. Ketiga, Australian Criminal Intelligence Commission (ACIC) tahun 2016 yang berperan membantu ACLEI dalam mencegah, mendeteksi dan menyelidiki masalah korupsi terkait penegakan hukum (Transparency International Australia, 2016).

Selama tahun 2013-2017, aturan dan lembaga multi-agensi yang dibentuk Australia penulis mempersepsikan telah berperan penting dalam penegakan hukum di Australia, namun hal itu belum mampu untuk memberantas korupsi secara komprehensif. Australia belum mempunyai lembaga anti-korupsi tunggal yang membawahi setiap lembaga di bawah satu kerangka kohesif bersama, sehingga hal itu membuat pemberantasan korupsi selama periode 2013-2017 masih bersifat fluktuatif dan menyebabkan penurunan skor dalam CPI selama periode tersebut.Hal ini sejalan dengan pernyataan CEO Transparency International Australia Serena Lillywhite yang menyatakan bahwa Australia membutuhkan badan antikorupsi federal yang dirancang dengan baik dan berbasis luas sebagai bagian dari peningkatan strategi multi-agensi,memastikan pendekatan komprehensif terhadap risiko korupsi di luar sistem investigasi kriminal, danmendukung integritas parlementer yang lebih kuat (Transparency International Australia, 2018).

\section{Transparency}

Australia memiliki dua sistem hukum penting dalam memastikan transparansi dan pengendalian korupsi. Pertama, Freedom of Information Act 1982 yang memberikan hak kepada masyarakat untuk mengakses dokumen pemerintah. Kedua, Public Interest Disclosure Laws atau disebut juga Whistleblower Protection Laws yang melindungi karyawan sektor publik dari 
tuduhan atau tindakan hukum jika karyawan tersebut melaporkan korupsi yang dilakukan karyawan lain (Australian Government, 2012).

Selama periode 2013-2017, pelaksanaan transparansi Australia masih mendapatkan kritikan, misalnya karena masih terdapatnya penolakan akses terhadap dokumen yang dilakukan pemerintah Australia berdasarkan laporan The Guardian Australia. The Guardian Australia mengidentifikasi bahwa masih banyak informasi pemerintah yang dirahasiakan. Pada tahun 2013-2014, sebesar 13,2\% permohonan Freedom of Information (FOI) ditolak oleh pemerintah federal, tahun 2014-2015 sebesar 10,3\%, tahun 2015-2016 dan 2016-2017 sebesar $10 \%$. Kemudian persentase tersebut naik pada periode 2017-2018 sebesar 16,2\%. The Guardian Australia menemukan lebih dari 2.000 permintaan FOI membutuhkan waktu tiga bulan lebih lama daripada kerangka waktu menurut undang-undang untuk diselesaikan, hal ini membuat semua dokumen itu tidak lagi relevan pada saat mereka dirilis (The Guardian Australia, 2019). Berdasarkan data di atas, penulis memandang bahwa FOI belum bekerja secara maksimal dan masih perlu pengkajian lebih lanjut untuk meningkatkan transparansi Australia sebagai salah satu upaya pencegahan korupsi.

\section{Equity}

Australia memiliki Australian Public
Service Commission (APSC) yang bertanggungjawab dalam memajukan layanan publik secara terbuka, adil, tidak memihak, apolitis, dan menunjung tinggi nilai serta kode etik yang diatur dalam Public Service Act 1999. Selama periode2013-2017, tingkat keadilan Australia masih mendapat kritikan, seperti masih adanya pelanggaran kode etik berupakronisme dan nepotisme. Bahkan, menurut The Guardian Australia bentuk korupsi seperti kronisme dan nepotisme tersebut telah meningkat secara signifikan dalam tiga tahun terakhir. Survei yang dilakukan oleh APSC mengungkapkan bahwa $5 \%$ dari pegawai negeri melaporkan menyaksikan pelanggaran tersebut pada tahun 2016-2017. Angka tersebut merupakan peningkatan yang signifikan dari 2,6\% pada tahun 2013-2014 dan 3,6\% pada tahun 2014-2015. Bentuk pelanggaran kronisme merupakan yang paling umum disaksikan dan menyumbang dua pertiga dari seluruh respon, kemudian diikuti nepotisme (26\%), serta "green light," keputusan yang dilakukan secara memihak, tidak pantas, dan merugikan orang lain (21\%) (The Guardian Australia, 2018). Berdasarkan data tersebut, penulis memandang bahwa selama periode20132017 masih terdapat bentuk ketidakadilan seperti kronisme dan nepotisme yang menyumbang angka korupsi di Australia dan perlu pengkajian lebih lanjut terkait kinerja APSC dalam memaksimalkan nilai-nilai yang sesuai dengan kode etik tersebut.

\section{Effectiveness and Efficiency}

Secara umum lembaga antikorupsi di Australia memiliki peran yang sama. Pertama, peran operasional yang mencakup pemantauan, pengawasan, dan penginvestigasian dugaan korupsi baik berdasarkan rujukan dari pemerintah, pengaduan dari anggota masyarakat, maupun inisiatif dari lembaga tersebut. Kedua, peran dalam mencegah korupsi dengan melakukan penilaian terhadap sistem kelembagaan, memberikan saran, sertamelakukan pelatihan dan penelitian. Ketiga, peran dalam pendidikan publik dengan menjalankanprogram kesadaran pubik terhadap dampak korupsi dan meminta dukungan publik untuk melaporkan korupsi (McMillan, 2008).

Setiap lembaga antikorupsi telah menjalankan tugasnya masing-masing, namun menurut David Harper, mantan Hakim Pengadilan Banding di Mahkamah Agung Victoria, ICAC NSW merupakan lembaga antikorupsi yang paling efektif dari semua lembaga antikorupsi negara bagian. Hal ini karena ICAC NSW memiliki yurisdiksi 
yang luas untuk menyelidiki setiap tindakan yang dapat memengaruhi pelaksanaan jabatan publik yang tidak memihak dan memiliki kekuatan investigasi yang kuat. Audiensi publik yang dilakukan ICAC NSW juga menjadikania lebih efektif dalam mengekspos korupsi. Menurut Harper, tidak adanya badan antikorupsi nasional yang efektif menjadi alasan mengapa Australia tidak pernah bebas dari korupsi (The Sydney Morning Herald, 2018). Hal ini juga didukung oleh survei Global Corruption Barometer yang menyatakan bahwa dua pertiga warga Australia mendukung pembentukan badan antikorupsi federal tersebut (The Guardian Australia, 2018).

Impact - menyimpulkan tingkat keberhasilan UNCAC dalam memberantas korupsi di Australia.

Berdasarkan data di atas dan jika dilihat dari angka korupsi Australia yang masih bersifat fluktuatif, penulis menilaibahwa selama periode2013-2017 lembaga antikorupsi Australia belum sepenuhnya efektif dan efisien dalam memberantas korupsi. Salah satu penyebabnya adalah karena Australia belum memiliki lembaga anti-korupsi federal yang mengatur dan mengawasi seluruh lembaga anti-korupsi di bawah kerangka hukum yang kohesif. Kurangnya efektivitas lembaga-

\section{DAFTAR PUSTAKA}

\section{Buku dan Jurnal}

Abdurofiq, A. (2016). Politik Hukum Ratifikasi Konvensi PBB Anti Korupsi di Indonesia. Jurnal Cita Hukum, 187208.

Assegaf, R. (2015). Policy Analysis and Educational StrategyCorruption in Indonesia and Singapore. International Journal of Asian Social Science, 611625.

Gulo, W. (2000). Metodologi Penelitian.

Jakarta: PT. Grasindo. lembaga anti-korupsi tersebut juga dibuktikan dalam nilai indikator government effectiveness berdasarkan WGI Project, dimana skor Australia turundari 2013 ke 2014 (dari nilai 94,79 ke 92,31), kemudian stagnan dengan nilai 92,31 selama periode 2013-2017.

\section{KESIMPULAN}

Implementasi UNCAC di Australia selama periode 2013-2017 hanya berpengaruh pada peningkatan jumlah agensi anti-korupsi baik di tingkat negara bagian maupun federal, namun tidak berbanding lurus dengan semakin berkurangnya kasus korupsi dan meningkatnya skor serta peringkat CPI Australia. Hal itu terjadi karena tidak semua agensi anti-korupsi tersebut terbukti bekerja secara efektif, diikuti pandangan bahwa pembentukan mereka hanya untuk memastikan agar setiap negara bagian memiliki lembaga anti-korupsi tanpa adanya kepastian penerapan akuntabilitas dan kinerja yang efektif. Kedua, beberapa penerapan good governance selama periode 2013-2017 juga masih mendapatkan kritik. Ketiga, beberapa aturan hukum yang dijadikan dasar implementasi beberapa pasal UNCAC masih membutuhkan pengkajian lebih lanjut karena beberapa hambatan dan kritik.

Haggard, S., \& Simmons, B. (1987). Theories of International Regimes. International Organization, 491-517.

Leiken, R. S. (1996). Controlling The Global Corruption Epidemic. Social Science Premium Collection.

Mitchell, Z., Merrington, S., \& Bell, P.A. Comparative Analysis of the OECD Anti-Corruption Models (Asia \& Europe) And Australia's Existing AntiCorruption Platform. International Journal of Business and Commerce, 123.

Perwita, A. A., \& Yani, Y. M. (2005). Pengantar Ilmu Hubungan Internasional. Bandung: Rosda. 
Puspito, N. T., \& dkk. (2011). Pendidikan Anti Korupsi Untuk Perguruan Tinggi. Jakarta: Kementerian Pendidikan dan Kebudayaan RI.

Sarwono, J. (2006). Metode Penelitian Kuantitatif dan Kualitatif. Yogyakarta: Graha Ilmu.

Uslaner, E. M. (2012). The Roots of Corruption: Mass Education, Economic Inequality and State Building. 1-39.

Yoshimatsu, H. (1998). International Regimes, International Society, and Theoretical Relations.ICSEAD (pp. 115). Kitakyushu: The International Centre for the Study of East Asian Development.

\section{Internet}

Arnold, Luke. (2017). Australian National Statement - Seventh Session of The Conference of The States Parties to The UN Convention Against Corruption. Diakses dari https://austria.embassy.gov.au/vien/ UNCAC17Stmnt.html.

Aulby, H., \& Campbell, R. (2018). "The Cost of Corruption." Australia Institute. Diakses dari http://www.tai.org.au/sites/defualt/f iles/P381\%20Costs\%20of\%20corrup tion\%20FINAL.pdf.

Australian Commission of Law Enforcement Integrity. (2014). "ACLEI Annual Report 2013-2014." Diakses dari https://www.aclei.gov.au/sites/g/file s/net846/f/documents/Reports\%20s ubmissions\%20and\%20speeches/AC LEIAnnualReport2013-2014.pdf.

Australian Commission of Law Enforcement Integrity. (2015). "ACLEI Annual Report 2014-2015." Diakses dari https://www.aclei.gov.au/sites/g/file s/net846/f/documents/ACLEIAnnual-Report-2014-15.pdf.

Australian Commission of Law Enforcement Integrity. (2016). "ACLEI Annual Report 2015-2016." Diakses dari https://www.aclei.gov.au/sites/g/file s/net846/f/aclei_annual_report_1516.pdf?v=1476225843.

Australian Commission of Law Enforcement Integrity. (2017). "ACLEI Annual Report 2016-2017." Diakses dari https://aclei.govcms.gov.au/sites/g/fi les/net846/f/aclei_ar_2016-17.pdf.

Australian Commission of Law Enforcement Integrity. (2019). "ACLEI's Role."

Diakses dari

https://www.aclei.gov.au/acleis-role.

Australian Government. (2012). "Australia's Approach to Fighting Corruption."

Diakses dari

http://unpan1.un.org/intradoc/group s/public/documents/apcity/unpan04 7794.pdf.

Big Assignments Australia. (2016). "Role and Impact of The Rules of Equity in Australia's Legal System." Diakses dari https://bigassignments.com/samples /role-and-impact-of-the-rules-ofequity-in-australia-legal-system.

Commonwealth of Australia. (2018). "Economic References Committee: Foreign Bribery." Diakses dari https://www.aph.gov.au/ /media/Co mmittees/economics_ctte/Foreignbri bery 45 th/report.pdf?la=en.

Corruption and Crime Commission. (2014). "CCC WA Annual Report 2013-2014."

Diakses dari

https://www.ccc.wa.gov.au/sites/def ault/files/Corruption\%20and\%20Cri me\%20Commission\%20Annual\%20R eport\%202013-2014.pdf.

Corruption and Crime Commission. (2015). "CCC WA Annual Report 2014-2015."

Diakses dari

https://www.ccc.wa.gov.au/sites/def ault/files/Corruption\%20and\%20Cri me\%20Commission\%20Annual\%20R eport\%202014-2015.pdf.

Corruption and Crime Commission. (2016). "CCC WA Annual Report 2015-2016."

Diakses dari

https://www.ccc.wa.gov.au/sites/def ault/files/Corruption\%20and\%20Cri 
me\%20Commission\%20Annual\%20R eport\%202015-16\%20_0.pdf.

Corruption and Crime Commission. (2017). "CCC WA Annual Report 2016-2017."

Diakses dari

https://www.ccc.wa.gov.au/sites/def ault/files/Corruption\%20and\%20Cri me\%20Commission\%20Annual\%20R eport\%202016-2017.pdf.

Crime and Corruption Commission. (2015).

"CCC Queensland Annual Report

2014-2015." Diakses dari

https://www.parliament.qld.gov.au/d ocuments/tableOffice/TabledPapers/ 2015/5515T1140.pdf.

Crime and Corruption Commission. (2016).

"CCC Queensland Annual Report

2015-2016." Diakses dari

https://www.parliament.qld.gov.au/d ocuments/tableOffice/TabledPapers/ 2016/5516T1623.pdf.

Crime and Corruption Commission. (2017). "CCC Queensland Annual Report 2016-2017." Diakses dari http://www.ccc.qld.gov.au/researchand-

publications/publications/ccc/corpor ate/ccc-annual-report-2016-

17/section-05-financial-informationccc-annual-report-2016-

17.pdf/download.

Crime and Misconduct Commission. (2014).

"CMC Queensland Annual Report

2013-2014." Diakses dari

http://www.ccc.qld.gov.au/researchand-

publications/publications/corporate/ annual-report-2013-14/annualreport-2013-14.pdf/download.

Donaldson, David. (2019). "Corruption Perception Index: Australia Failing To Improve." Diakses dari https://www.themandarin.com.au/10 3451-corruption-perceptions-indexaustralia-failing-to-improve/.

IBAC Victoria. (2014). "IBAC Victoria Annual Report 2013-2014." Diakses dari https://www.ibac.vic.gov.au/docs/def ault-source/reports/web-pdf---ibacannual-report-2013-14--20140926.pdf?sfvrsn=51996575_22.

IBAC Victoria. (2015). "IBAC Victoria Annual Report 2014-2015." Diakses dari

https://www.parliament.vic.gov.au/fil e_uploads/IBAC_Annual_report_201415_H2jPfMNp.pdf.

IBAC Victoria. (2016). "IBAC Victoria Annual Report 2015-2016." Diakses dari https://www.ibac.vic.gov.au/docs/def ault-source/reports/ibac-annualreport-2015-16.pdf

IBAC Victoria. (2017). "IBAC Victoria Annual Report 2016-2017." Diakses dari https://www.ibac.vic.gov.au/docs/def ault-source/reports/ibac-annualreport-2016-17.pdf.

IBAC Victoria. (2019). "About Us." Diakses dari https://www.ibac.vic.gov.au/aboutus.

ICAC NSW. (2014). "ICAC NSW Annual Report 2013-2014." Diakses dari http://www.icac.nsw.gov.au/docume nts/about-the-icac/corporatereporting/4519-annual-report-20132014/file.

ICAC NSW. (2015). "ICAC NSW Annual Report 2014-2015." Diakses dari https://www.icac.nsw.gov.au/docman /about-the-icac/corporatereporting/4675-annual-report-2014$15 /$ file.

ICAC NSW. (2016). "ICAC NSW Annual Report 2015-2016." Diakses dari https://www.icac.nsw.gov.au/docman /about-the-icac/corporatereporting/4901-annual-report-201516-final/file.

ICAC NSW. (2017). "ICAC NSW Annual Report 2016-2017." Diakses dari https://www.icac.nsw.gov.au/docman /about-the-icac/corporatereporting/5023-icac-annual-report2016-17/file. 
ICAC NSW. (2019). "Overview." Diakses dari https://www.icac.nsw.gov.au/aboutthe-nsw-icac/overview.

ICAC OPI. (2014). "ICAC SA \& OPI Annual Report 2013-2014." Diakses dari https://icac.sa.gov.au/system/files/2 013-2014-ICAC-and-OPI-AnnualReport_0.pdf.

ICAC OPI. (2015). "ICAC SA \& OPI Annual Report 2014-2015." Diakses dari https://icac.sa.gov.au/system/files/2 014-

2015_ICAC_OPI_Annual_Report_0.pdf.

ICAC OPI. (2016). ICAC SA \& OPI Annual Report 2015-2016. Diakses dari https://icac.sa.gov.au/system/files/2 015-

16_ICAC_OPI_Annual_Report_0.pdf.

ICAC OPI. (2017). "ICAC SA \& OPI Annual Report 2016-2017." Diakses dari https://icac.sa.gov.au/system/files/2 016-

2017_ICAC_OPI_Annual_Report.pdf.

International Fund For Agriculture Development. (1999). "Good Governance: An Overview." Diakses dari

http://www.ipa.government.bg/sites/ default/files/pregleddobro_upravlenie.pdf.

King, \& Mallesons, Wood. (2018). "Australia Praised for Enforcement of Foreign Bribery Offences." Diakses dari https://www.lexology.com/library/de tail.aspx?g=d589f11b-b936-4404aaab-227fa0659510.

KPMG Australia. (2017). "KPMG Survey Reveals Surge in Fraud in Australia." Diakses dari https://home.kpmg/au/en/home/me dia/press-releases/2017/01/surgefraud-i-aus-fraud-barometer-25-jan2017.html.

McKenzie, Nick, dkk. (2016). "World's Biggest Bribe Scandal. " Diakses dari https://www.theage.com.au/interacti ve/2016/the-bribe-factory/day2/global-investigation.html.
McMillan, John. (2008). "Introduction to Anti-Corruption Law and Policy in Australia. " Diakses dari https://www.ombudsman.gov.au/_d ata/assets/pdf_file/0018/33039/2627-May-2008-Introduction-to-anticorruption-law-and-policy-inAustralia.pdf.

Redlich, Holding. (2018). "Anti-Corruption and Bribery in Australia." Diakses dari https://www.lexology.com/library/de tail.aspx?g=02c36883-d097-4d1b82dc-cfad89766570.

Stokke, Olav Schram. 2006. "Determining The Effectiveness of Internatioal Regimes." Diakses dari http://www.svt.ntnu.no/iss/fagkonfe ranse2007/intern/papers/olav.s.stok ke@fni.noStokkeDetermRegimeEffecti veness.PDF.

Tasmanian Integrity Commission. (2014). "TIC Annual Report 2013-2014." Diakses dari https://www.integrity.tas.gov.au/_da ta/assets/pdf_file/0010/297415/Inte grity_Annual_report_2013_2014.pdf.

Tasmanian Integrity Commission. (2015). "TIC Annual Report 2014-2015." Diakses dari https://www.integrity.tas.gov.au/_da ta/assets/pdf_file/0005/329036/Inte grity_Commission_Annual_Report_201 4-2015_WEB.pdf.

Tasmanian Integrity Commission. (2016). "TIC Annual Report 2015-2016." Diakses dari https://www.integrity.tas.gov.au/_da ta/assets/pdf_file/0011/359498/Inte grity_Commission_Annual_Report_201 5_2016.pdf.

Tasmanian Integrity Commission. (2017). "TIC Annual Report 2016-2017." Diakses dari https://www.integrity.tas.gov.au/_da ta/assets/pdf_file/0005/394430/Ann ual-Report_IC_17-10-17_Final.pdf.

The Guardian Australia. (2017). "Fears Australia's Political Donations System is Eroding Faith in Democracy." 
Diakses dari

https://www.theguardian.com/austra lia-news/2017/sep/07/fearsaustralias-political-donations-systemis-eroding-faith-in-democracy.

The Guardian Australia. (2018).

"Overwhelming Majority of

Australians Believe Federal Politicians

Are Corrupt." Diakses dari

https://www.theguardian.com/austra

lia-

news/2018/aug/21/overwhelming-

majority-of-australians-believe-

federal-politicians-are-corrupt.

The Guardian Australia. (2018). "Public

Servants Report Rise in Corruption,

Prompting Calls for Federal

Watchdog." Diakses dari

https://www.theguardian.com/austra

lia-news/2018/jan/10/public-

servants-report-rise-in-corruption-

prompting-calls-for-federal-watchdog.

The Guardian Australia. (2019). "How A

Flawed Freedom of Information

Regime Keeps Australians In The

Dark." Diakses dari

https://www.theguardian.com/austra lia-news/2019/jan/02/how-a-flawedfreedom-of-information-regimekeeps-australians-in-the-dark.

The Sydney Morning Herald. (2018).

"Australia Becoming More Corrupt,

Warns Former Judge." Diakses dari

https://www.smh.com.au/national/a ustralia-becoming-more-corruptwarns-former-judge-20181113p50fsp.html.

The Worldwide Governance Indicators.

(2017). "The Worldwide Governance

Indicators Project." Diakses dari http://info.worldbank.org/governanc e/wgi/index.aspx\#home.

Transparency International. (2017).

"Corruption Perception Index 2017."

Diakses dari

https://www.transparency.org/news

/feature/corruption_perceptions_inde x_2017.
Transparency International. (2017). People and Corruption: Asia Pasific-Global Corruption Barometer. Diakses dari http://tict.niceenterprise.com/ezcatfil es/tict/img/img/2701/2017_GCB_Asi aPacific_EN.pdf.

Transparency International Australia. (2016). "Anti-Corruption Agencies in Australia." Diakses dari http://transparency.org.au/wpcontent/uploads/2016/01/PP3-AntiCorruption-Agencies-TransparencyInternational-Australia-Jan-2016.pdf.

Transparency International Australia. (2016). "Open Government and Rights to Information." Diakses dari http://transparency.org.au/tia/wpcontent/uploads/2016/10/PP5-OpenGovernment-Rights-to-InformationTransparency-International-AustraliaJan-2016.pdf.

Transparency International Australia. (2017). "A Federal Anti-Corruption Agency for Australia?" Diakses dari https://www.accountabilityrt.org/wp -content/uploads/2017/03/GriffithUniversity-National-Integrity-2017Discussion-Paper-A-Federal-AntiCorrution-Agency-for-AustraliaMarch-2017.pdf.

Transparency International Australia. (2018). "Media Release: A Federal Integrity and Anti-Corruption Commission on The Horizon." Diakses dari http://transparency.org.au/icac/. United Nations. (2012). "Review of Implementation of the UNCAC." Diakses dari https://documents-ddsny.un.org/doc/UNDOC/GEN/V12/536 /16/PDF/V1253616.pdf?OpenElemen $\mathrm{t}$.

United Nations. (2019). "Review of Implementation of the UNCAC." Diakses dari https://www.unodc.org/documents/t reaties/UNCAC/WorkingGroups/Impl ementationReviewGroup/ExecutiveSu mmaries2/V1808730e.pdf. 
United Nations Office on Drugs and Crime. (2014). "Legal Library." Diakses dari https://track.unodc.org/LegalLibrary /pages/LegalResources.aspx?country $=$ Australia.
United Nations Office on Drugs and Crime. (2019). "What is Good Governance?" Diakses dari https://www.unodc.org/e4j/en/anticorruption/module-2/keyissues/what-is-good-governance.html. 